\title{
PENDIDIKAN SEJARAH DALAM PENDIDIKAN KARAKTER BANGSA
}

\author{
Muhammad Mukhlis \\ Email: 1810111310008@mhs.ulm.ac.id \\ Program Studi Pendidikan Sejarah Fakultas Keguruan dan Ilmu Pendidikan \\ Universitas Lambung Mangkurat \\ Banjarmasin
}

\begin{abstract}
Abstrak
Pendidikan merupakan upaya terencana dalam mengembangkan potensi anak didik sehingga mereka memiliki sistem berpikir, nilai, moral, dan keyakinan yang diwariskan masyarakatnya dan mengembangkan warisan tersebut ke arah yang sesuai untuk kehidupan masa kini dan masa mendatang.

Pendidikan karakter merupakan proses untuk menuntun peserta didik menjadi manusia seutuhnya yang berkarakter dalam hati, raga, pikir, serta rasa dan karsa. Pendidikan karakter dapat dimaknai sebagai pendidikan nilai, pendidikan budi pekerti, pendidikan moral, pendidikan watak, yang bertujuan mengembangkan kemampuan peserta didik untuk memberikan keputusan baik buruk, memelihara apa yang baik, dan mewujudkan kebaikan itu dalam kehidupan sehari-hari dengan sepenuh hati (Samani, 2011:45).

Pendidikan sejarah merupakan pendidikan yang sangat penting untuk mengajarkan kepada peserta didik akan pentingnya sejarah sebagai pembentuk kepribadian siswa. Sartono Kartodirdjo dalam (Susanto, 2014:35) berpendapat bahwa dalam rangka pembangunan bangsa, pengajaran sejarah tidak semata mata berfungsi untuk memberikan pengetahuan sejarah sebagai kumpulan informasi fakta sejarah tetapi juga bertujuan menyadarkan anak didik atau membangkitkan kemampuan berpikir kesejarahannya.
\end{abstract}

\section{PENDAHULUAN}

Kaimuddin dalam jurnal bertajuk Implementasi Pendidikan Karakter dalam Kurikulum 2013 (2014), pendidikan karakter merupakan usaha sadar yang terencana dan terarah melalui lingkungan pembelajaran untuk tumbuh kembangnya seluruh potensi manusia yang memiliki watak berkepribadian baik, bermoral-berakhlak, dan berefek positif konstruktif pada alam dan masyarakat. 
Pengertian pendidikan karakter sendiri dapat dipahami dari tiap-tiap katanya secara terpisah. Pendidikan merupakan proses pembelajaran kebiasaan, keterampilan, dan pengetahuan manusia yang diteruskan dari generasi sebelumnya kepada generasi berikutnya. Sementara itu, karakter merupakan akumulasi watak, sifat, dan kepribadian individu yang mengarah pada keyakinan dan kebiasaannya dalam kehidupan sehari-hari.

Banyak persoalan yang terjadi pada masyarakat Indonesia dewasa ini, seperti korupsi, kekerasan, pencurian, perampokan, kejahatan seksual, perkelahian massa (antar para pelajar, pemuda antara kampung/desa), kehidupan ekonomi yang konsumtif, kehidupan politik yang tidak produktif, dan sebagainya.

Maraknya sikap dan perilaku buruk sehingga Indonesia yang dikenal penyabar, ramah, penuh sopan santun, dan pandai berbasa-basi, sekonyong-konyong menjadi pemarah, suka mencaci, dan pendendam. "Dalam tiga dekade terakhir Indonesia banyak kehilangan mulai dari sumber daya alam, manusia, dan budaya," (Dasim, 2011).

Tidak mudah untuk menyelesaikan persoalan yang ada dalam waktu singkat. Pemberian hukum yang berat, ternyata tidak membuat orang jera malah bisa sebaiknya. Untuk itu perlu ada alternatif lain. Alternatif penyelesaian yang dikemukakan untuk mengatasi, paling tidak mengurangi, persoalan mengenai masalah budaya dan karakter bangsa adalah pendidikan.

\section{TUJUAN PENDIDIKAN SEJARAH}

Pendidikan merupakan upaya terencana dalam mengembangkan potensi anak didik sehingga mereka memiliki sistem berpikir, nilai, moral, dan keyakinan yang diwariskan masyarakatnya dan mengembangkan warisan tersebut ke arah yang sesuai untuk kehidupan masa kini dan masa mendatang. Pendidikan dianggap sebagai alternatif yang bersifat preventif karena pendidikan membangun generasi baru bangsa yang lebih baik. Sebagai alternatif yang bersifat preventif, pendidikan diharapkan dapat mengembangkan kualitas generasi muda bangsa dalam berbagai aspek yang dapat memperkecil dan mengurangi penyebab berbagai masalah budaya dan karakter bangsa yang ramai diperbincangkan. Memang diakui bahwa hasil dari pendidikan dampaknya tidak dapat dilihat dalam waktu yang singkat, perlu proses, pembiasaan sehingga memiliki daya tahan dan dampak yang kuat di masyarakat.

Pendidikan karakter merupakan proses untuk menuntun peserta didik menjadi manusia seutuhnya yang berkarakter dalam hati, raga, pikir, serta rasa dan karsa. Pendidikan karakter 
dapat dimaknai sebagai pendidikan nilai, pendidikan budi pekerti, pendidikan moral, pendidikan watak, yang bertujuan mengembangkan kemampuan peserta didik untuk memberikan keputusan baik buruk, memelihara apa yang baik, dan mewujudkan kebaikan itu dalam kehidupan sehari-hari dengan sepenuh hati (Samani, 2011:45).

Pendidikan karakter tidak hanya melalui pembelajaran seperti Pendidikan Kewarganegaraan saja, namun pendidikan karakter juga bisa diperoleh melalui pembelajaran sejarah. Pendidikan sejarah merupakan pendidikan yang sangat penting untuk mengajarkan kepada peserta didik akan pentingnya sejarah sebagai pembentuk kepribadian siswa. Sartono Kartodirdjo dalam (Susanto, 2014:35) berpendapat bahwa dalam rangka pembangunan bangsa, pengajaran sejarah tidak semata mata berfungsi untuk memberikan pengetahuan sejarah sebagai kumpulan informasi fakta sejarah tetapi juga bertujuan menyadarkan anak didik atau membangkitkan kemampuan berpikir kesejarahannya.

Menurut Hamid Hasan, dalam (Susanto, 2014;35), menyatakan bahwa:

1. Pendidikan sejarah memberikan materi pendidikan yang mendasar, mendalam dan berdasarkan pengalaman bangsa di masa lalu untuk membangun kesadaran dan pemahaman tentang diri dan bangsanya.

2. Materi pendidikan sejarah merupakan materi pendidikan yang khas dalam membangun kemampuan berpikir logis, kritis, analisis, dan kreatif yang sesuai dengan tantangan kehidupan yang dihadapi pada masanya.

3. Pendidikan sejarah menyajikan materi dan contoh keteladanan, kepemimpinan, kepeloporan, sikap dan tindakan manusia dalam kelompoknya yang menyebabkan terjadinya perubahan perubahan dalam kehidupan manusia tersebut.

4. Kehidupan manusia selalu terikat dengan masa lampau karena walaupun hasil tindakan dalam menjawab tantangan bersifat final tetapi hasil dari tindakan tersebut selalu memiliki pengaruh yang tidak berhenti hanya untuk masanya tetapi berpengaruh terhadap masyarakat tadi dalam menjalankan kehidupan barunya, dan oleh karena peristiwa sejarah menjadi "bank of examples" untuk digunakan dan di sesuaikan sebagai tindakan dalam menghadapi tantangan kehidupan masa kini.

Apabila keempat poin di atas dapat terlaksana dengan baik maka terlaksanalah tujuan dari pendidikan sejarah itu. 


\section{PENDIDIKAN SEJARAH SEBAGAI PENGUAT PENDIDIKAN KARAKTER}

Proses pendidikan karakter menurut Muhaimin (1996:153) dapat diaplikasikan padapelajaran sejarah yaitu melalui beberapa tahap, yaitu:

1) Tahap transformasi nilai, merupakan suatu proses yang dilakukan oleh pendidik dalam menginformasikan nilai-nilai pendidikan karakter. Pada tahap ini hanya terjadi komunikasi verbal antara pendidik dan peserta didik;

2) Tahap transaksi nilai, merupakan tahapan untuk menyajikan pendidikan karakter melalui komunikasi dua arah atau interaksi antara peserta didik dengan pendidik yang bersifat timbal balik;

3) Tahap transinternalisasi, merupakan tahapan dimana penerapan pendidikan karakter dilakukan tidak hanya melalui komunikasi verbal, melainkan juga dengan sikap mental dan kepribadian ke dalam diri peserta didik. Pada tahapan ini, komunikasi kepribadian yang dijalankan pendidik kepada peserta didik lebih dominan dan berperan secara aktif.

Materi yang termuat dalam mata pelajaran sejarah memiliki ciri khas yang kuat untuk memperkenalkan bagaimana sejarah perjuangan bangsa dan aspirasi generasi terdahulu dalam upaya mewujudkan cita cita bersama sebagai negara yang berdaulat, nilai nilai yang terkandung dari peristiwa penting bangsa inilah yang akan menumbuhkan karakter seperti cinta tanah air dan semangat kebangsaan yang akan melahirkan rasa bangga menjadi bagian dari bangsa ini.

Penjabaran di atas juga diperkuat oleh pendapat Kasmadi (1996:13) yang menjelaskan tentang tujuan pembelajaran sejarah adalah untuk menanamkan semangat kebangsaan, cinta tanah air, bangsa dan negara. Menumbuhkan karakter peserta didik agar sesuai dengan tujuan pendidikan nasional tentu tidak semudah yang di bayngkan, harus di barengi dengan kebiasaan kebiasaan positif yang dilakukan secara berkesinambungan dalam lingkungan kelas seperti membuka pembelajaran dengan di sisipkan lagu lagu kebangsaan, kemudian memperkenalkan tokoh tokoh bangsa indonesia yang turut serta berjuang untuk bangsa ini, mempelajari biografi pahlawan, serta mengarahkan peserta didik akan pentingnya menghargai waktu, selanjutnya mengimplementasikan dalam kebiasaan sehari hari dengan tidak terlambat kesekolah, ini adalah sebagian upaya yang dapat dilakukan secara berkesinambungan untuk melakukan kebiasaan yang positif dalam lingkungan nyata. 


\section{KESIMPULAN}

Pendidikan merupakan upaya terencana dalam mengembangkan potensi anak didik sehingga mereka memiliki sistem berpikir, nilai, moral, dan keyakinan yang diwariskan masyarakatnya dan mengembangkan warisan tersebut ke arah yang sesuai untuk kehidupan masa kini dan masa mendatang. Pendidikan karakter tidak hanya melalui pembelajaran seperti Pendidikan Kewarganegaraan saja, namun pendidikan karakter juga bisa diperoleh melalui pembelajaran sejarah. Pendidikan sejarah merupakan pendidikan yang sangat penting untuk mengajarkan kepada peserta didik akan pentingnya sejarah sebagai pembentuk kepribadian siswa. Dalam rangka pembangunan bangsa, pengajaran sejarah tidak semata mata berfungsi untuk memberikan pengetahuan sejarah sebagai kumpulan informasi fakta sejarah tetapi juga bertujuan menyadarkan anak didik atau membangkitkan kemampuan berpikir kesejarahannya.

\section{REFERENSI}

Anis, M. Z. A., Putro, H. P. N., Susanto, H., \& Hastuti, K. P. (2020). Historical Thinking Model in Achieving Cognitive Dimension of Indonesian History Learning. PalArch's Journal of Archaeology of Egypt/Egyptology, 17(7), 7894-7906.

Anis, M. Z. A. (2020). Pendidikan Sejarah Berbasis Pendidikan Karakter.

https://akupintar.id/info-pintar/-/blogs/pendidikan-karakter-pengertian-nilai-danimplementasinya

http://sejarah.upi.edu/artikel/dosen/pengembangan-pendidikan-karakter-dalam-pembelajaransejarah/

https://www.google.com/url?sa=t\&source=web\&rct=j\&url=https://ejournal.undiksha.ac.id/in dex.php/JIIS/article/viewFile/16527/9920\%23: :text\%3DPembelajaran\%2520sejarah\% 2520sebagai\%2520pendukung\%2520pendidikan,mendasari\%2520proses\%2520pembe ntukan\%2520karakter\%2520dan\&ved=2ahUKEwiV9dnq2JjwAhW463MBHcJnAvwQ FjABegQIAxAG\&usg=AOvVaw2uGXnhhEPx7fKUppSVKY97 